\title{
"Ceria"
}

Jurnal Program Studi Pendidikan Anak Usia Dini

ISSN 2301-9905

Volume 7, No. 2, Januari 2018

Fakultas Keguruan dan Ilmu Pendidikan - Universitas Muhammadiyah Tangerang

\section{Upaya Meningkatkan Percaya Diri Melalui Kegiatan Menyanyi Pada Anak Usia 5-7 Tahun Di RA Tarbiatul Umi Kota Tangerang}

\author{
${ }^{1}$ Maslihah, ${ }^{2}$ Titi Rachmi \\ 1,2 Program Studi Pendidikan Guru Pendidikan Anak Usia Dini; Fakultas \\ Keguruan dan Ilmu Pendidikan; Universitas Muhammadiyah Tangerang \\ Email : maslihahazzam@gmail.com, titi rachmi@yahoo.com
}

\begin{abstract}
Abstrak
Penelitian ini berangkat dari rumusan masalah apakah terdapat peningkatan melalui kegiatan menyanyi terhadap percaya diri anak pada usia 5-7 tahun di RA Tarbiatul Umi, Kecamatan Periuk, Kota Tangerang. Tujuan penelitian ini untuk mengetahui adanya peningkatan percaya diri anak usia 5-7 tahun, dan apakah kegiatan menyanyi dapat meningkatkan percaya diri anak usia 5-7 tahun di RA Tarbiatul Umi, Kecamatan Periuk, Kota Tangerang Semester II tahun 2016/2017. Model kegiatan penelitian yang digunakan adalah kegiatan Menyanyi. Rancangan penelitian mengacu pada alur Penelitian Tindakan Kelas dimulai dari perencanaan, pelaksanaan, observasi, dan refleksi yang dilakukan secara bersiklus. Subyek penelitian ini adalah kelompok B yang berjumlah 12 anak yang terdiri dari anak laki-laki dan anak perempuan. Data dikumpulkan secara observasi, wawancara, dan dokumentasi, selanjutnya dianalisis secara deskriptif kualitatif dengan teknik persentase. Dapat disimpulkan bahwa kegiatan menyanyi dapat meningkatkan percaya diri anak usia 5-7 tahun, terbukti terjadi peningkatan dari siklus I ke siklus III $68 \%$ menjadi $97 \%$. Siklus I sampai siklus III dapat diperoleh tingkat presentase $29 \%$. Selama penelitian percaya diri anak usia 5-7 tahun mengalami peningkatan yang signifikan.
\end{abstract}

Kata Kunci : Percaya Diri, Kegiatan Menyanyi, Anak Usia 5-7 Tahun

\section{Pengantar}

Dalam perkembangan sosialnya, anak usia dini sudah harus dituntut dengan keberanian, masalah keberanian ini lekat dengan percaya diri. Menurut Mulyani (2016) percaya diri adalah modal penting yang harus dimiliki oleh seluruh anak dalam menjalani proses kehidupannya, tanpa rasa percaya diri sulit bagi anak untuk mampu mengeksplorasi kemampuan atau potensi yang 
dimilikinya (h.133). Anak yang tidak memiliki percaya diri akan mengalami berbagai macam kesulitan dan hambatan dalam proses interaksi sosialnya. Sifat pemalu pada anak akan menghambat mereka untuk bersosialisasi dengan orang lain. Selain itu, anak yang tidak percaya diri akan memiliki rasa takut ketika harus berinteraksi dengan lingkungan di luar keluarga. Memiliki anak yang memiliki percaya diri tentunya menyenangkan, karena dengan percaya diri yang mereka miliki ini dapat menciptakan prestasi dalam kehidupan mereka nantinya, dan juga keberhasilan dalam bersosialisasi tentunya.

Guru anak usia dini dituntut untuk mampu bisa membuat suasana menyenangkan. Khususnya adalah dengan nyanyian, guru anak usia dini harus pandai menyanyi dan membuat anak bergembira dan berani melalui kegiatan menyanyi. Menurut Wiyani dan Barnawi (2012), kegiatan menyanyi merupakan salah satu kegiatan yang sangat digemari oleh anak (h.131). Melalui nyanyian atau lagu banyak hal yang dapat kita pesankan kepada anak - anak, terutama pesan-pesan moral dan nilai-nilai agama. Melalui kegiatan menyanyi suasana pembelajaran akan lebih menyenangkan, menggairahkan, membuat anak bahagia, menghilangkan rasa sedih, anak-anak merasa terhibur dan lebih bersemangat, sehingga pesan-pesan yang kita berikan akan lebih mudah dan cepat diterima serta diserap oleh anak-anak. Berdasarkan observasi yang telah dilaksanakan pada kelas B di RA. Tarbiatul Umi Periuk Tangerang, masih terlihat adanya percaya diri yang rendah pada anak di RA. Tarbiatul Umi. Dari 12 anak hanya terlihat 5 anak yang berani tampil di depan kelas, yang lainnya masih belum bisa tampil percaya diri. Pembelajaran yang dilakukan oleh guru di RA. Tarbiatul Umi pun kurang menghidupkan nyanyian. Kurangnya motivasi guru ketika kegiatan menyanyi di awal kegiatan KBM, Guru terkadang lupa dengan menyisipkan nyanyian, bahkan tidak ada nyanyian sama sekali pada kegiatan KBM nya, guru mengejar target anak mempersiapkan masuk sekolah dasar. 
Percaya diri merupakan modal dasar bagi anak untuk menunjukkan kemampuan dirinya. Anak-anak yang memiliki percaya diri tinggi merupakan pribadi yang bisa dan mau belajar, serta berprilaku positif dalam berhubungan dengan orang lain bahkan orang dewasa sekali pun. Yoder dan Proctor (2011) mengemukakan bahwa anak dapat dikatakan memiliki percaya diri tinggi jika anak tersebut aktif namun tidak berlebihan. Tidak mudah terpengaruh dengan orang lain, mudah bergaul, berfikir positf, penuh tanggung jawab, energik dan tidak mudah putus asa, dapat bekerjasama serta mempunyai jiwa pemimpin juga merupakan definisi percaya diri menurut Rahayu (2011, h. 69).

Sejak dalam kandungan sampai lahir anak telah dibekali bakat, kemampuan salah satunya adalah percaya diri. Miskell (2011) mengemukakan bahwa percaya diri adalah penilaian yang relatif tentang diri sendiri, mengenai kemampuan bakat, kepemimpinan dan inisiatif, serta sifat-sifat lain dan kondisi yang mewarnai perasaan manusia (Rahayu, 2011, h. 64). Dapat diartikan bahwa percaya diri merupakan tindakan untuk menunjukkan kemampuan diri dalam setiap kegiatan.

Percaya dalam diri anak diawali dengan memiliki perasaan positif yang membawa anak menjadi nyaman dengan dirinya maupun lingkungan. Ketika anak sudah merasa nyaman, akan timbul percaya diri dan keberanian yang ditujukan melalui tindakan yang akan membuahkan hasil, kenyamanan anak ini pula harus didukung oleh lingkungan, khususnya institusi pendidikan. Hal ini senada dengan Baswedan (Naura, 2015) bahwa salah satu kunci keberhasilan pendidikan adalah percaya diri yang besar dari orang dewasa terhadap anak (h.1). Percaya bahwa mereka berdaya, penuh potensi dan kreativitas, serta mampu memecahkan masalah nyata disekitar mereka.

Berdasarkan definisi yang telah dipaparkan oleh para ahli, maka dapat disimpulkan bahwa percaya diri merupakan penilaian tentang diri sendiri mengenai keberanian, kepemimpinan dan kenyamanan yang akan menjadi acuan dalam meningkatkan percaya diri anak usia 5-7 tahun. 
Setiap anak memiliki tahapan perkembangan masing-masing sesuai usianya, secara bertahap anak mampu berkembang secara optimal ketika dilandasi dengan rangsangan atau stimulus yang baik. Menurut Cannela (2010) bahwa sebagian besar anak Usia 5 tahun berada dalam fase yang cukup tenang dan semakin tinggi percaya dirinya dan rasa untuk mengendalikan dirinya (Allen\&Marotz, 2010, h.148). Menurut Wiyani (2014) menyebutkan bahwa perkembangan percaya diri anak usia 5-7 Tahun sudah dapat muncul dengan dengan kemampuan : mau memimpin dalam setiap kegiatan, berani tampil di depan umum, menunjukan ketenangan disetiap kegiatan, mau mengemukakan pendapat secara sederhana, mengambil keputusan secara sederhana, bermain pura-pura atau main peran tentang suatu profesi, bekerja secara mandiri, berani bercerita sederhana (h.134).

Dapat disimpulkan artinya bahwa pencapaian percaya diri pada anak usia 5-7 tahun ini seharusnya sudah muncul. Namun pada kenyataannya anak-anak usia 5-7 tahun belum tentu semuanya memiliki kemampuan percaya diri. Hal ini dipengaruhi oleh lingkungan sekitar anak yang mendukung proses perkembangan percaya diri anak.

Kegiatan untuk meningkatkan percaya diri anak salah satunya dengan menggunakan kegiatan menyanyi, menyanyi merupakan kegiatan yang menyenangkan, menyanyi dapat menumbuh kembangkan kecerdasan ganda anak. Tarwiyah (2012) mengatakan menyanyi adalah bahasa, bahasa dalam bentuk syair lagu menjadi bagian yang penting dalam menumbuh kembangkan kecerdasan ganda anak (h.7). Melalui kegiatan menyanyi dapat mengembangkan kemampuan bahasa anak, sehingga anak dapat berinteraksi dengan lingkungan sekitar.

Dengan melibatkan anak dalam kegiatan menyanyi bersama secara tidak langsung kita telah memberikan pengalaman yang menyenangkan kepada mereka. Hal ini senada dengan Kamtini (Risaldy, 2014, h. 90) menyanyi merupakan sarana pengungkapan pikiran dan perasaan, sebab kegiatan 
menyanyi penting bagi pendidikan anak-anak, selain itu menyanyi adalah kegiatan menyenangkan yang memberi kepuasan kepada anak- anak.

Berdasarkan pemaparan para ahli tersebut di atas dapat disimpulkan menyanyi merupakan bahasa sebagai ungkapan pikiran dan perasaan melalui sebuah lantunan lagu yang berirama. Lebih sederhananya penulis mengartikan menyanyi merupakan bahasa yang berirama. Irama yang keluar melalui bahasa ini bisa membuat hati yang melantunkannya senang ataupun sedih tergantung dari bahasa dan irama yang dinyanyikannya.

\section{Metode}

Menurut Kemmis seperti yang dikutip oleh Wiriaatmadja (2008, h. 12) menjelaskan bahwa penelitian tindakan adalah sebuah bentuk inkuiri reflektif yang dilakukan secara kemitraan mengenai situasi sosial tertentu (termasuk pendidikan) untuk meningkatkan rasionalitas dan keadilan dari praktek sosial atau pendidikan yang mereka lakukan, serta mempertinggi pemahaman mereka terhadap praktek dan situasi di mana praktek itu dilaksanakan. Dengan demikian dalam penelitian tindakan dilakukan secara kemitraan dengan orangorang yang terlibat dalam penelitian mengenai situasi yang dihadapi dalam kegiatan sosial serta pemahaman mengenai kegiatan praktek tersebut agar dapat mencapai situasi yang memungkinkan terlaksana kegiatan tersebut. Senada dengan Kusuma dan Dwitagama (2012, h. 9) penelitian tindakan kelas (PTK) adalah penelitian yang dilakukan oleh guru dikelasnya sendiri dengan cara ; 1) merencanakan, 2) melaksanakan, 3) merefleksikan tindakan secara kolaboratif dan partisipasif dengan tujuan memperbaiki kinerjanya sebagai guru, sehingga hasil belajar siswa dapat meningkat.

Tindakan yang dilakukan pada PTK ini adalah untuk meningkatkan Percaya diri melalui kegiatan Menyanyi pada anak usia 5-7 tahun. Dalam penelitian tindakan kelas terdapat beberapa model yang dapat dijadikan sebagai acuan dalam membuat desain PTK, diantaranya adalah model Kurt Lewin, 
"Ceria"

Jurnal Program Studi Pendidikan Anak Usia Dini

model John Elliot, model Dave Ebbut, model Kemmis \& Mc Taggart dan masih banyak yang lainnya. Dari beberapa model tersebut peneliti akan menggunakan model Kemmis \& Mc Taggart. Menurut Kemis dan Mc Taggart dalam Wiriaatmadja (2014, h.66) model PTK pada hakekatnya berupa perangkatperangkat dengan terdiri dari empat komponen yaitu ; 1) rencana, 2) tindakan, 3) pengamatan, 4) refleksi.

\section{Hasil Dan Pembahasan}

Percaya diri Anak di RA Tarbiatul Umi dapat ditingkatkan melalui Kegiatan Menyanyi . Ini dapat dilihat dari hasil pemberian tindakan pada setiap siklusnya mengalami kenaikan. 
Tabel 1.1

Deskriptif Data Percaya Diri Anak Usia 5-7 Tahun

Dari Kondisi Awal, Siklus I, Siklus II dan Siklus III

\begin{tabular}{cccccc}
\hline \multirow{2}{*}{ Nama } & \multicolumn{5}{c}{ Presentase } \\
\cline { 2 - 5 } Anak & Kondisi & Siklus I & Siklus II & Siklus III & $\begin{array}{c}\text { Peningkatan } \\
\text { Presentase }\end{array}$ \\
\hline AR & Awal & & & & $69 \%$ \\
ALF & $30 \%$ & $61 \%$ & $83 \%$ & $97 \%$ & $67 \%$ \\
AYN & $25 \%$ & $50 \%$ & $69 \%$ & $92 \%$ & $67 \%$ \\
AN & $25 \%$ & $50 \%$ & $67 \%$ & $92 \%$ & $67 \%$ \\
AFFH & $75 \%$ & $83 \%$ & $89 \%$ & $100 \%$ & $25 \%$ \\
BMA & $30 \%$ & $61 \%$ & $83 \%$ & $94 \%$ & $67 \%$ \\
MTA & $75 \%$ & $86 \%$ & $92 \%$ & $100 \%$ & $25 \%$ \\
JFR & $30 \%$ & $53 \%$ & $72 \%$ & $94 \%$ & $64 \%$ \\
JLPN & $78 \%$ & $92 \%$ & $94 \%$ & $100 \%$ & $22 \%$ \\
RVLD & $30 \%$ & $56 \%$ & $78 \%$ & $94 \%$ & $64 \%$ \\
QN & $75 \%$ & $82 \%$ & $86 \%$ & $100 \%$ & $25 \%$ \\
ZDN & $78 \%$ & $89 \%$ & $94 \%$ & $100 \%$ & $22 \%$ \\
\hline Rata - & $48 \%$ & $68 \%$ & $82 \%$ & $97 \%$ & $49 \%$ \\
rata & & & & & \\
\hline
\end{tabular}

Berdasarkan hasil perbandingan Percaya diri anak anak melalui kegiatan nyanyi pada pra penelitian, siklus I, siklus II dan siklus III, maka dapat dilihat terjadinya peningkatan. Jika dilihat dari data yang diperoleh adanya peningkatan siklus I dari pra penelitian sebesar $68 \%$, dan peningkatan siklus I dari siklus II sebesar 82\% sedangkan peningkatan siklus II dari siklus III sebesar 97\%. Hal ini dapat dilihat dari skor yang diperoleh setiap anak tampak semakin meningkat. Perbandingan antara sebelum dilakukan tindakan dan sesudah dilakukan tindakan terjadi peningkatan, dan sudah melampaui indikator 
keberhasilan yang ditetapkan, sebelum penelitian berlangsung yaitu sebesar $75 \%$. Jadi penelitian ini bisa dikatakan telah berhasil karena peningkatan anak sebesar 97\%. Dengan demikian kegiatan menyanyi mampu meningkatkan Percaya diri Anak anak usia 5-7 tahun di RA Tarbiatul Umi Kecamatan Periuk Kota Tangerang.

Pentingnya percaya diri yang harus distimulus sejak usia dini terlihat ketika ia berada dalam situasi apapun, anak yang memiliki percaya diri adalah anak yang memiliki rasa nyaman, seperti yang dinyatakan oleh Risman (2013) rasa ini sangat berkaitan dengan rasa nyaman seseorang tentang diri sendiri, anak yang memiliki percaya diri adalah anak yang diawali dengan memiliki perasaan positif yang membawa anak menjadi nyaman dengan diri sendiri maupun lingkungan (Puspitarini, 2013, h. 6). Ketika anak sudah merasa nyaman, akan timbul percaya diri dan keberanian yang ditunjukan melalui suatu tindakan yang akan membuahkan hasil. Berdasarkan hasil tersebut orang lain akan menilai dan mengakui sehingga anak tersebut akan merasa nyaman dengan diri maupun lingkungannya. Menyanyi membuat anak senang dan akhirnya memunculkan percaya diri. Hal ini diperkuat dengan Penelitian yang dilakukan oleh Lina Marlina (2011) yang bertujuan untuk meningkatkan kepercayaan diri anak usia 5-6 tahun melalui bermain peran di kelompok B. Implikasi dari penelitian ini bahwa bermain peran dalam pembelajaran pada anak dapat dijadikan alternative untuk meningkatkan kepercayaan diri pada anak.

Kegiatan menyanyi dilakukan dengan menggunakan media Audio Visual (Laptop), sebelum guru mengeluarkan alat tersebut guru memberi peraturan terlebih dahulu supaya kegiatan hari ini dapat berjalan dengan baik, setelah itu guru mengajak anak-anak menyanyikan lagu bebas yang anak sudah tau, kemudian guru memperlihatkan nyanyian yang ada di Laptop dan anak tampak senang dan fokus memperhatikan nyanyian yang diperlihatkan oleh guru, akhirnya guru mengajak anak-anak untuk menyanyi bersama-sama dan anak- 
anak mengikutinya, namun masih ada beberapa anak yang belum fokus mengikuti nyanyian yang diajarkan oleh guru.

Selesai memperlihatkan nyanyian tersebut guru mengajak anak-anak untuk menyanyi bersama-sama, ada beberapa anak yang antusias mengikuti nyanyian tersebut ada beberapa anak juga yang masih belum mengikutinya bahkan tidak keluar suara sama sekali. Guru mempersilahkan anak untuk maju kedepan secara bersama-sama mengulang nyanyian tersebut, kemudian secara berkelompok menyanyi kedepan. Anak-anak terlihat senang dan mulai nyaman terhadap diri sendiri ketika kegiatan berlangsung. Setelah selesai kegiatan menyanyi anak-anak duduk melingkar dan guru menanyakan bagaimana perasaan dalam kegiatan menyanyi hari ini, anak-anak pun kemudian masuk kedalam pembahasan mengupas tema, sub tema pembahasan hari ini, anak-anak merasa gembira dengan awalan pembelajaran hari ini, menunjukan ekspresi senangnya dan meminta kegiatan tersebut dilakukan pada hari esok

Setelah selesai bermain jam 10.00 anak-anak masuk kembali dan belajar membaca kemudian sebagian anak latihan menulis. Jam menunjukan jam 10.30 anak-anak bersiap untuk pulang, sebelum pulang guru memberikan motivasi kepada anak agar tetap semangat dalam melakukan kegiatan selanjutnya. Selesai memberikan motivasi guru bertanya kepada anak siapa yang mau memimpin doa sebelum pulang, setelah ada yang bersedia dan berani memimpin doa sebelum pulang maka guru mempersilahkan anak untuk memimpin doa dan diikuti oleh teman-teman yang lainnya. Selesai berdoa anak menyanyi bersamasama. Setelah itu anak-anak pulang secara bergiliran dan tertib, anak-anak salim kepada semua guru dan mengucapkan salam sebelum meninggalkan kelas dan pulang kerumah masing-masing.

\section{Kesimpulan}

Dengan menggunakan kegiatan Menyanyi pada pembelajaran anak usia 57 tahun di RA TARBIATUL UMI, suasana pembelajaran menjadi lebih 
menyenangkan. Anak-anak sangat antusias sekali dalam melaksanakan kegiatan menyanyi, sehingga percaya diri anak dapat tersimulus dan berkembang dengan baik. Berdasarkan hasil penelitian pada siklus I, menunjukan adanya peningkatan percaya diri anak antara sebelum dan sesudah pemberian tindakan pada anak usia 5-7 tahun di RA TARBIATUL UMI. Hal ini dibuktikan dengan adanya peningkatan sebesar $20 \%$ yakni dari kondisi awal $48 \%$ menjadi $68 \%$, siklus II mengalami peningkatan sebesar $34 \%$, yakni dari kondisi awal $48 \%$ menjadi $82 \%$. Pada siklus III mengalami peningkatan sebesar $49 \%$, pada kondisi awal $48 \%$ menjadi $97 \%$, sehingga dapat disimpulkan bahwa kegiatan menyanyi dapat meningkatkan percaya diri anak pada usia 5-7 tahun di RA TARBIATUL UMI Kecamatan Periuk Kota Tangerang.

Kesimpulan di atas hasil dari penelitian tindakan kelas tersebut ada beberapa hal yang harus ditindak lanjuti yaitu :1). Bagi guru perlu mengetahui teknik menyanyi yang dapat meningkatkan percaya diri anak, 2). Bagi sekolah, penelitian ini diharapkan dapat memberikan masukan untuk meningkatkan kualitas pembelajaran, 3). Bagi mahasiswa, dapat menjadi acuan untuk penelitian selanjutnya.

Kegiatan menyanyi secara bersama-sama, berkelompok dan individu dapat meningkatkan percaya diri anak dan menumbuhkan keberanian pada anak sehingga dapat menumbuhkan jiwa kepemimpinan pada diri anak masingmasing. Kegiatan menyanyi telah diterapkan di sekolah ini untuk kedepan yang lebih baik dengan alat musik yang bervariasi dan berbagai jenis nyanyian yang mudah difahami oleh anak. 


\section{Daftar Acuan}

Allen, K Allen dan Lynn Marotz. (2010). Profile Perkembangan Anak Pra Kelahiran Hingga 12 Tahun. Penerjemah Valentino. Jakarta : Indeks.

Kusuma dan Dwitagama. (2012). Penelitian Tindakan Kelas. Jakarta : Indeks

Mulyani. (2016). Saatnya Tampil Beda dengan Percaya Diri. Yogyakarta : Araska

Puspitarini, Henny. (2013). Membangun Rasa Percaya Diri Anak. Jakarta : Penerbit PT Elex Media Komputindo

Rahayu, Afriyanti Yofita. (2011). Menumbuhkan Kepercayaan Diri Melalui BermainBercerita. Jakarta : PT Indeks.

Risaldy, Sabil. (2014). Bermain, Bercerita dan Menyanyi Bagi Anak Usia Dini. Jakarta : Penerbit PT Luxima Metro Media

Tarwiyah. (2012). Jurnal Pendidikan PAUD.

Tim Naura Books \& Taman Gagagasan. (2015). Aku Bisa.Bandung : Noura Books

Wiraatmadja. (2008). Metode Penelitian Tindakan Kelas. Bandung : Remaja Rosda Karya

Wiyani, Ardy Novan. (2014). Mengelola dan Mengembangkan Kecerdasan Sosial $\mathcal{E}$ Emosi Anak Usia Dini. Yogyakarta : Ar-Ruzz Media.

Wiyani dan Barnawi .(2012). Format PAUD Konsep Karakteristik \& Implementasi Pendidikan Anak Usia Dini. Yogyakarta : Ar-Ruzz Media. 